\title{
STATUS KEBERSIHAN GIGI DAN MULUT SISWA SMA NEGERI 9 MANADO PENGGUNA ALAT ORTODONTIK CEKAT
}

\author{
${ }^{1}$ Ravenske E. C Momongan \\ ${ }^{2}$ Benedictus S. Lampus \\ ${ }^{3}$ Juliatri
}

\author{
${ }^{1}$ Kandidat Skripsi Program Studi Pendidikan Dokter Gigi Fakultas Kedokteran \\ ${ }^{2}$ Bagian Ilmku Kesehatan Masyarakat Fakultas Kedokteran \\ ${ }^{3}$ Program Studi Pendidikan Dokter Gigi Fakultas Kedokteran \\ Universitas Sam Ratulangi Manado \\ Email: ravenska170111@gmail.com
}

\begin{abstract}
Fixed orthodontic appliance has been widely used in society, but they are often not aware of the risk of the use of fixed orthodontic appliances such as dental and oral hygiene problems. Design tool fixed orthodontic makethe dental cleaning procedure becomes more difficult. Oral hygiene is maintained in the user less dental appliance, such as the user orthodontic appliances can cause periodontal tissue damage and increasing the number of caries during treatment. This study is a descriptive study in order to determine the status of oral and dental hygiene students of Public Senior High School 9 Manado users fixed orthodontic appliances. The study population is the students of Public Senior High School 9 Manado fixed orthodontic appliance users who were attending school classes XI and XII. Samples numbered 39 people and sampling carried out with total sampling method. The research instrument was a check list form and interview. Assessment of dental and oral hygiene status was obtained by measuring the score Simplified Oral Hygiene Index (OHI-S). The results showed that the average of OHI-S scores in SMA Negeri 9 Manado was 1,22. By sex as much as 3 boys (7,7\%) had a score of OHI-S 0,83 and a total of 36 girls $(92,3 \%)$ had a score of OHI-S 1,23; based on the socio-economic level as much as 6 students (15,4\%) with moderate socioeconomic level had OHI-S score of 1,97 and a total of 33 students $(84,6 \%)$ in the high socioeconomic level had OHI-S score of 1,06. Period of $<1$ year usage by 25 students $(64,1 \%)$ had a score of OHI-S 1.05; 1-2 years as many as 12 respondents $(30.8 \%)$ had a score of OHI-S 1,15 and >2 years two respondents $(5,1 \%)$ had a score of OHI-S 1.5.Oral hygiene status of the student-sex male and female average is fair. Oral hygiene statuses of students with socio-economic level of parents are on average quite good and students with low socioeconomic level average moderate. Oral hygiene status of students who use a fixed orthodontic appliance under 1 year and 1-2 years on average quite good and more than 2 years on average moderate. Oral hygiene status of the student users fixed orthodontic appliances in general quite good.
\end{abstract}

Keywords : Fixed orthodontic, dental and oral hygiene.

\footnotetext{
Abstrak: Alat ortodontik cekat sudah banyak digunakan dalam masyarakat, namun mereka sering tidak menyadari risiko penggunaan alat ortodontik cekat seperti masalah kebersihan gigi dan mulut. Desain alat ortodontik cekat menyebabkan prosedur pembersihan gigi dan mulut menjadi lebih sulit. Kebersihan gigi dan mulut yang kurang terjaga pada pengguna dental appliance, seperti pada pengguna alat ortodontik dapat menyebabkan kerusakan jaringan periodontal dan meningkatnya jumlah karies selama perawatan. Penelitian ini merupakan penelitian deskriptif dengan tujuan untuk mengetahui status kebersihan gigi dan mulut siswa SMA Negeri 9 Manado pengguna alat ortodontik cekat. Populasi penelitian yaitu siswa SMA Negeri 9 Manado pengguna alat ortodontik cekat yang duduk dibangku sekolah
} 
kelas XI dan XII. Sampel berjumlah 39 orang dan pengambilan sampel dilakukan dengan metode total sampling. Instrumen penelitian berupa formulir check list dan wawancara. Penilaian status kebersihan gigi dan mulut diperoleh dengan pengukuran skor Oral Hygiene Index Simplified (OHI-S). Hasil penelitian menunjukkan skor OHI-S rata-rata siswa SMA Negeri 9 Manado sebesar 1,22. Berdasarkan jenis kelamin sebanyak 3 siswa laki-laki $(7,7 \%)$ memiliki skor OHI-S 0,83 dan sebanyak 36 siswa perempuan (92,3\%) memiliki skor OHI-S 1,23; berdasarkan tingkat sosial ekonomi sebanyak 6 siswa $(15,4 \%)$ dengan tingkat sosial ekonomi sedang memiliki skor OHI-S 1,97 dan sebanyak 33 siswa $(84,6 \%)$ pada tingkat sosial ekonomi tinggi memiliki skor OHI-S 1,06. Lama penggunaan $<1$ tahun sebanyak 25 siswa $(64,1 \%)$ memiliki skor OHI-S 1,$05 ; 1-2$ tahun sebanyak 12 responden $(30,8 \%)$ memiliki skor OHI-S 1,15 dan $>2$ tahun ada 2 responden $(5,1 \%)$ memiliki skor OHI-S 1,5. Status kebersihan gigi dan mulut siswa berjenis kelamin laki-laki dan perempuan rata-rata tergolong baik. Status kebersihan gigi dan mulut siswa dengan tingkat sosial ekonomi orang tua sedang rata-rata tergolong baik dan siswa dengan tingkat sosial ekonomi rendah rata-rata tergolong sedang. Status kebersihan gigi dan mulut siswa yang menggunakan alat ortodontik cekat di bawah 1 tahun dan 1- 2 tahun rata-rata tergolong baik dan lebih dari 2 tahun rata-rata tergolong sedang. Status kebersihan gigi dan mulut siswa pengguna alat ortodontik cekat pada umumnya tergolong baik.

Kata kunci: alat ortodontik cekat, kebersihan gigi dan mulut.

Kesehatan gigi dan mulut merupakan bagian dari kesehatan tubuh yang tidak dapat dipisahkan satu dan lainnya karena akan memengaruhi kesehatan tubuh secara keseluruhan. Gigi berperan penting dalam proses pengunyahan, berbicara dan mempertahankan bentuk muka, sehingga adanya masalah pada gigi akan dapat mengganggu fungsi atau peran gigi.

Berdasarkan hasil Survei Kesehatan Rumah Tangga (SKRT) Departemen Kesehatan Republik Indonesia (Depkes RI) tahun 2010 menunjukkan, bahwa 63 penduduk Indonesia menderita penyakit gigi dan mulut, antara lain penyakit karies gigi dan penyakit periodontal. Data hasil Riset Kesehatan Dasar (RISKESDAS) tahun 2013 yang dikeluarkan Departemen kesehatan RI melaporkan, bahwa prevalensi masalah gigi dan mulut penduduk Indonesia mencapai 25,9\%. Hasil tersebut menunjukkan bahwa terjadi peningkatan prevalensi masalah gigi dan mulut sebesar 2,7 bila dibandingkan dengan hasil RISKESDAS tahun 2007. Berdasarkan data Dinas Kesehatan tahun 2013, Sulawesi Utara diperkirakan memiliki $57 \%$ karies aktif dari usia 15 tahun ke atas. ${ }^{1}$

Penyakit karies gigi dan periodontal antara lain disebabkan oleh kebersihan gigi dan mulut yang buruk. Kebersihan gigi dan mulut dipengaruhi oleh perilaku pemeliharaan kebersihan gigi dan mulut individu, pemakaian gigi tiruan, pemakaian alat ortodontik baik lepasan maupun cekat, jenis kelamin, tingkat sosial ekonomi. Alat ortodontik merupakan alat yang digunakan dalam perawatan ortodontik yang bertujuan untuk memperbaiki susunan gigi yang tidak teratur. Dewasa ini perawatan ortodontik atau lebih dikenal dengan perawatan kawat gigi menarik perhatian banyak orang, tidak terkecuali anak-anak dan remaja. Kebanyakan dari mereka melakukan perawatan alat ortodontik untuk memperbaiki penampilan dan memberi rasa percaya diri. ${ }^{2}$

Perawatan ortodontik bertujuan untuk memperbaiki fungsi, mendapat struktur seimbang, estetis dan harmonis pada perawatan maloklusi atau susunan gigi tidak teratur, namun pada kenyataannya seringkali pemakaian alat ortodontik berdampak pada kerusakan gigi dan jaringan penunjang dari pengguna alat ortodontik. Desain alat ortodontik baik lepasan maupun cekat menyebabkan pengguna alat ortodontik mengalami kesulitan dalam menjaga kebersihan gigi dan mulutnya. Struktur alat yang digunakan memudahkan sisa makanan mudah 
tersangkut pada komponen alat ortodontik, sehingga pengguna alat ortodontik rentan mengalami kerusakan pada gigi dan jaringan penunjangnya. Lamanya perawatan yang harus dijalani oleh pengguna alat ortodontik akan turut memengaruhi kesehatan gigi dan mulutnya. ${ }^{3}$

Penggunaan alat ortodontik di kalangan remaja terutama pada usia 14-17 tahun, bukan lagi sekedar pemenuhan kebutuhan akan perawatan akan tetapi sudah menjadi tuntutan pemenuhan gaya hidup. Besarnya biaya yang dibutuhkan untuk perawatan ini menyebabkan pengguna alat ini biasanya berasal dari golongan ekonomi menengah ke atas. Di samping itu remaja berjenis kelamin perempuan cenderung lebih banyak menggunakan alat ini dibandingkan remaja berjenis kelamin laki-laki oleh karena alasan penampilan. ${ }^{4}$

Berdasarkan latar belakang di atas penulis tertarik untuk meneliti bagaimana status kebersihan gigi dan mulut pada siswa sekolah menengah atas (SMA) yang menggunakan alat ortodontik cekat. Berdasarkan survei awal yang dilakukan di SMA Negeri 9 Manado, penulis menemukan cukup banyak siswa pengguna alat ortodontik cekat dan pada lokasi ini belum pernah dilakukan penelitian sejenis serta mudah dijangkau.

\section{BAHAN DAN METODE}

Penelitian ini merupakan penelitian deskriptif dengan desain cross- sectional yang dilaksanakan di Sekolah SMA Negeri 9 Manado selang bulan Agustus 2014. Populasi dalam penelitian ini yaitu seluruh siswa kelas XI dan XII yang menggunakan alat ortodontik cekat. Pengambilan sampel dilakukan dengan total sampling. Sampel yang di teliti yaitu siswa yang kooperatif. Pengumpulan data yang digunakan dengan melakukan pemeriksaan OHI-S untuk mengukur indeks debris dan indeks kalkulus dan wawancara digunakan untuk memperoleh data pendukung dari subjek penelitian. Cara Kerja yaitu Subjek duduk tenang lalu diinstruksikan membuka mulut untuk diperiksa gigi geliginya. Dilakukan pemeriksaan debris yaitu pada gigi molar pertama kanan atas (16) bagian bukal, insisivus pertama kanan atas (11) pada bagian labial, molar pertama kiri atas (26) pada bagian bukal, molar pertama kiri bawah (36) pada bagian lingual, insisivus pertama kiri bawah (31) pada bagian labial, dan molar pertama kanan bawah (46) pada bagian lingual, diikuti dengan pemeriksaan kalkulus pada gigi geligi yang sama dengan menggunakan kaca mulut dan sonde. Pasien berkumur selama 10 detik dan dilakukan wawancara. Penghitungan indeks debris dan indeks kalkulus untuk pengukuran OHI-S. Status kebersihan gigi dan mulut diukur berdasarkan oral hygiene index simplified (OHI-S) yang diperkenalkan oleh Green dan Vermilion pada tahun 1964 dengan menjumlahkan debris index simplified (DI-S) dan calculus index simplified (CI-S). Data yang telah dikumpulkan kemudian diolah dengan cara manual dan dihitung persentasenya kemudian disajikan dalam bentuk tabel distribusi frekuensi dan dianalisis. Penilaian untuk DI-S dan CI-S dapat dilihat pada gambar 1 .

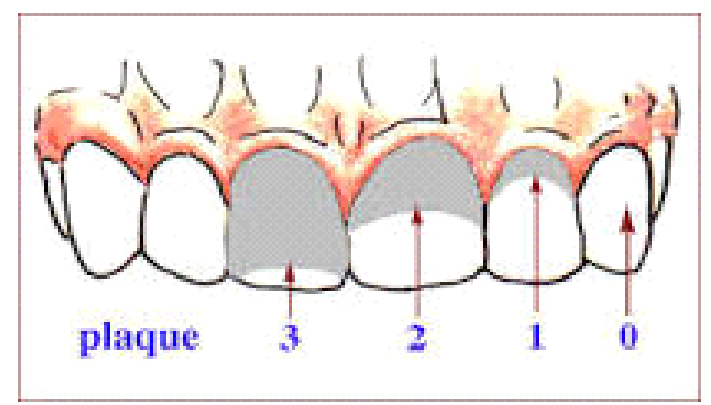

Gambar 1. Cara penilaian DI-S dan CI-S

Nilai $0=$ Tidak ada debris, kalkulus $1=$ Ditutup debris, kalkulus lunak tidak lebih dari $1 / 3$ permukaan gigi, $2=$ Debris, kalkulus lunak menutupi lebih dari $1 / 3$ tapi tidak lebih dari $2 / 3$ permukaan gigi, $3=$ Debris, kalkulus lunak menutupi lebih dari 2/3 permukaan gigi. Skor DI-S dan CI-S masing-masing dapat diperoleh dengan jumlah skor permukaan gigi dibagi dengan jumlah gigi yang diperiksa. Setelah 
dilakukan pemeriksaan DI-S dan CI-S, maka penilaian OHI-S dapat diketahui dengan menjumlahkan DI-S dan CI-S. ${ }^{5}$

\section{HASIL PENELITIAN}

Hasil penelitian diperoleh melalui pemeriksaan kebersihan gigi dan mulut, jenis kelamin, tingkat sosial ekonomi, lama penggunaan pada pengguna alat ortodontik cekat.

Tabel 1. Distribusi frekuensi responden penelitian berdasarkan jenis kelamin

\begin{tabular}{ccc}
\hline Jenis kelamin & $\mathrm{N}$ & $\%$ \\
\hline Laki-laki & 3 & 7,7 \\
Perempuan & 36 & 92,3 \\
\hline Total & 39 & 100 \\
\hline
\end{tabular}

Tabel 2. Distribusi frekuensi tingkat sosial ekonomi responden berdasarkan penghasilan orang tua

\begin{tabular}{ccc}
\hline Sosial ekonomi & N & $\%$ \\
\hline Rendah & 0 & - \\
Sedang & 6 & 15,4 \\
Tinggi & 33 & 84,6 \\
\hline Total & 39 & 100 \\
\hline
\end{tabular}

Tabel 3. Distribusi frekuensi responden berdasarkan lama penggunaan alat ortodontik

\begin{tabular}{ccc}
\hline Lama penggunaan & $\mathrm{N}$ & $\%$ \\
\hline $0-12$ bulan & 27 & 69,2 \\
$13-24$ bulan & 10 & 25,7 \\
>24 bulan & 2 & 5,1 \\
Total & 39 & 100 \\
\hline
\end{tabular}

Tabel 4. Distribusi frekuensi kebersihan gigi dan mulut responden penelitian berdasarkan skor OHI-S

\begin{tabular}{ccccc}
\hline OHI-S & $\mathrm{N}$ & $\%$ & $\begin{array}{c}\text { Skor- } \\
\text { OHI-S }\end{array}$ & $\begin{array}{c}\text { Status kebersihan } \\
\text { gigi dan mulut }\end{array}$ \\
\hline Baik & 22 & 56,4 & 0,8 & Sedang \\
Sedang & 17 & 43,6 & 1,7 & Baik \\
Buruk & 0 & 0 & 0 & - \\
Total & 39 & 100 & $2,3 / 2$ & Baik \\
\hline
\end{tabular}

Tabel 5. Distribusi frekuensi status kebersihan gigi dan mulut rata-rata responden

\begin{tabular}{|c|c|c|c|}
\hline $\begin{array}{c}\text { Status } \\
\text { Kebersihan Gigi } \\
\text { \& Mulut }\end{array}$ & $\begin{array}{l}\text { Skor } \\
\text { DI-S }\end{array}$ & $\begin{array}{l}\text { Skor } \\
\text { CI-S }\end{array}$ & $\begin{array}{c}\text { Skor } \\
\text { OHI-S }\end{array}$ \\
\hline Baik & 0,78 & 0,42 & 1,22 \\
\hline
\end{tabular}

Tabel 6. Distribusi frekuensi status kebersihan gigi dan mulut responden berdasarkan jenis kelamin

\begin{tabular}{ccccc}
\hline $\begin{array}{c}\text { Jenis } \\
\text { kelami } \\
\mathrm{n}\end{array}$ & $\begin{array}{c}\text { Juml } \\
\text { ah } \\
(\mathrm{n})\end{array}$ & $\begin{array}{c}\text { Perse } \\
\text { ntase } \\
(\%)\end{array}$ & $\begin{array}{c}\text { Skor } \\
\text { OHI- } \\
\mathrm{S}\end{array}$ & $\begin{array}{c}\text { Status } \\
\text { Kebersihan } \\
\text { Gigi \& Mulut }\end{array}$ \\
\hline $\begin{array}{c}\text { Laki- } \\
\text { laki }\end{array}$ & 3 & 7,7 & 0,83 & Baik \\
$\begin{array}{c}\text { Perem } \\
\text { puan }\end{array}$ & 36 & 92,3 & 1,23 & Baik \\
\hline
\end{tabular}

Tabel 7. Distribusi frekuensi status kebersihan gigi dan mulut berdasarkan tingkat sosial ekonomi

\begin{tabular}{ccccc}
\hline $\begin{array}{c}\text { Tingkat } \\
\text { Sosial } \\
\text { Ekonomi }\end{array}$ & $\begin{array}{c}\text { Juml } \\
\text { ah } \\
(\mathrm{n})\end{array}$ & $\begin{array}{c}\text { Persen } \\
\text { tase } \\
(\%)\end{array}$ & $\begin{array}{c}\text { Skor } \\
\text { OHI- } \\
\text { S }\end{array}$ & $\begin{array}{c}\text { Status } \\
\text { Kebersih } \\
\text { an Gigi } \\
\& \text { Mulut }\end{array}$ \\
\hline Rendah & 0 & 0 & 0 & - \\
Sedang & 6 & 15,4 & 1,97 & Sedang \\
Tinggi & 33 & 84,6 & 1,06 & Baik \\
\hline
\end{tabular}

Tabel 8. Distribusi frekuensi status kebersihan gigi dan mulut berdasarkan lama penggunaan alat ortodontik cekat

\begin{tabular}{ccccc}
\hline $\begin{array}{c}\text { Lama } \\
\text { Penggu } \\
\text { naan } \\
\text { (tahun) }\end{array}$ & $\begin{array}{c}\text { Jumlah } \\
(\mathrm{n})\end{array}$ & $\begin{array}{c}\text { Perse } \\
\text { ntase } \\
(\%)\end{array}$ & $\begin{array}{c}\text { Skor } \\
\text { OHI-S }\end{array}$ & $\begin{array}{c}\text { Status } \\
\text { Kebersih } \\
\text { an Gigi } \\
\& \text { Mulut }\end{array}$ \\
\hline$<1$ & 25 & 64,1 & 1,05 & Baik \\
$1-2$ & 12 & 30,8 & 1,15 & Baik \\
$>2$ & 2 & 5,1 & 1,5 & Sedang \\
\hline
\end{tabular}

\section{BAHASAN}

Persentase responden berjenis kelamin perempuan yang menggunakan alat ortodontik cekat lebih banyak dari pada responden berjenis kelamin laki-laki. Perbedaan jumlah responden laki-laki dan perempuan kemungkinan dikarenakan 
perempuan lebih tidak percaya diri ketika terdapat malposisi pada gigi yang mengurangi nilai estetika pada dirinya. Pada laki-laki hal ini tidak terlalu menjadi perhatian, sehingga banyak pengguna alat ortodontik cekat ialah perempuan. Nilai estetika merupakan salah satu faktor yang memengaruhi seseorang menggunakan alat ortodontik cekat. Penelitian ini sama halnya dengan penelitian oleh Monica di Manado tahun 2014 yang menunjukkan dari 44 responden pengguna alat ortodontik cekat, $38(86 \%)$ di antaranya adalah responden berjenis kelamin perempuan dan sisanya adalah responden berjenis kelamin lakilaki. ${ }^{6}$

Keadaan sosial ekonomi orang tua responden pada tingkat sosial ekonomi tinggi lebih banyak dari tingkat sosial ekonomi sedang, dan tidak terdapat responden yang menggunakan alat ortodontik cekat pada tingkat sosial ekonomi rendah. Pada perawatan alat ortodontik cekat biaya yang dibutuhkan tidak sedikit, karena selain biaya pemasangan yang mahal ada juga biaya kontrol setiap bulannya sesuai dengan instruksi dokter gigi selama masa perawatan alat ortodontik cekat. Hal ini yang memunjukkan lebih banyak orang yang tingkat ekonomi tinggi, lebih memperhatikan keadaan gigi geliginya dibandingnya tingkat sosial ekonomi sedang. Salah satu faktor yang menjadi penghambat responden pada tingkat sosial ekonomi sedang yaitu keinginan untuk menjaga kebersihan gigi dan mulut membatasi mereka untuk melakukan perawatan gigi karena biaya yang cukup mahal.

Pada Tabel 6. menunjukkan responden yang menggunakan alat ortodontik cekat lebih banyak berada pada waktu kurang dari satu tahun, sedangkan pada waktu 1 -
2 tahun hanya 10 responden dan paling sedikit adalah responden penelitian yang menggunakan alat ortodontik cekat lebih dari 2 tahun. Waktu ideal yang dibutuhkan dalam perawatan ortodontik yaitu 1 tahun 6 bulan sampai 3 tahun disesuaikan tingkat keparahan maloklusi dari pasien itu sendiri, apabila keadaan gigi geliginya masih membutuhkan perawatan maka pemakaian alat ortodontik cekat masih tetap dilakukan.

Berdasarkan hasil penelitian OHI-S pada pengguna alat ortodontik cekat secara keseluruhan dari 39 responden yang diteliti, terdapat 22 responden (56,4\%)dengan kebersihan gigi dan mulut baik dan 17 responden $(43,6 \%)$ dengan kriteria sedang, dan tidak terdapatresponden yang memiliki kebersihan mulut buruk. Secara keseluruhan rata-rata kebersihan gigi dan mulut pengguna alat ortodontik cekat tergolong pada kriteria baik dengan hasil perhitungan OHI-S 1,2. Hal ini menunjukkan dari hasil pemeriksaan OHI$\mathrm{S}$, pengguna alat ortodontik cekat sangat memperhatikan kebersihan mulutnya.

Penelitian OHI-S pada pengguna alat ortodontik cekat berdasarkan jenis kelamin menunjukkan bahwa rata-rata penilaian OHI-S pada responden pengguna alat ortodontik cekat berjenis kelamin laki-laki dan perempuan sama yaitu berada pada kriteria baik, walaupun hasil ini tidak cukup valid mengingat jumlah responden yang diteliti untuk masing-masing jenis kelamin jumlahnya tidak berimbang. Berdasarkan hasil yang ada dapat diperoleh gambaran bahwa responden yang berjenis kelamin laki-laki dan perempuan memiliki perilaku yang baik dalam hal pemeliharaan kesehatan gigi dan mulut. Perilaku yang baik ini meliputi sikap dan pengetahuan yang baik sehingga mampu bertindak secara benardalam pemeliharaan kebersihan gigi dan mulut. Tindakan 
dimaksud antara lain meliputi menyikat gigi secara teratur dan benar, kontrol ke dokter gigi sesuai instruksi dokter gigi,dan lain sebagainya. Pada penelitian ini responden yang diteliti sebagian besar berjenis kelamin perempuan (92,3\%). Individu berjenis kelamin perempuan umumnya lebih menyukai hal-hal yang berkaitan dengan estetika, seperti berpenampilan rapih dan bersih karena mereka senang dipuji dan diperhatikan. Oleh karena itu kebersihan tubuh termasuk kebersihan gigi dan mulut merupakan salah satu hal yang turut menjadi perhatian perempuan agar bisa berpenampilan baik. Responden perempuan pengguna alat ortodontik cekat akan lebih memerhatikan kondisi giginya ketika ada sisa-sisa makanan menempel pada bracket, karena permukaan gigi yang kotor membuat responden tersebut tidak percaya diri dan dapat mengurangi nilai estetikanya. Penelitian Pimtip menunjukkan bahwa perempuan memiliki kemauan untuk lebih mencari perawatan dan peduli terhadap kesehatan mulut serta penampilannya dibandingkan dengan laki-laki. ${ }^{7}$

Berdasarkan perhitungan OHI-S pada pengguna alat ortodontik cekat dengan status sosial ekonomi tinggi, rata-rata berada pada kriteria baik. Status OHI-S pada responden dengan status sosial ekonomi sedang, rata-rata berada pada kriteria sedang. Hal ini menunjukkan bahwa responden dengan tingkat sosial ekonomi tinggi lebih memerhatikan kebersihan gigi dan mulutnya daripada responden dengan tingkat sosial ekonomi sedang. Status sosial ekonomi merupakan salah satu faktor yang memengaruhi kebersihan mulut. Perilaku individu yang benar dalam pemeliharaan kebersihan dan kesehatan gigi dan mulut awalnya terbentuk dari pengetahuan yang dimiliki baik dari orangtua, bangku pendidikan, media cetak, elektronik dan sebagainya. Berdasarkan penelitian yang dilakukan oleh Sogi dan Bhaskar di India, pada umumnya status kebersihan mulut lebih baik pada anak dengan status pekerjaan orang tua dari kalangan sosial ekonomi menengah ke atas dibandingkan dengan orang tua dari kalangan sosial ekonomi menengah ke bawah. Orang tua dari kalangan menengah ke atas menganggap pemeliharaan kesehatan gigi dan mulut lebih penting karena pada kalangan tersebut memiliki minat hidup sehat lebih besar. ${ }^{8}$

Perhitungan OHI-S rata-rata dengan lama penggunaan alat ortodontik cekat kurang dari 1 tahun, berada pada kriteria kebersihan gigi dan mulut baik. Hal ini sama dengan hasil yang diperoleh pada lama penggunaan $1-2$ tahun, yakni ratarata berada pada kriteria baik. Penulis berasumsi bahwa hal ini mungkin disebabkan karena responden sudah mampu menyerap instruksi tentang pemeliharaan kebersihan gigi dan mulut yang diberikan oleh dokter gigi selama menjalani perawatan. Pada masa perawatan awal responden lebih banyak kontak dengan dokter gigi yang merawatnya, sehingga pembentukan perilaku pemeliharaan kebersihan gigi dan mulut lebih terawasi dengan baik. Status OHI-S pada lama penggunaan lebih dari 2 tahun berada pada kriteria sedang. Penulis berpendapat hal ini menggambarkan perilaku respondennya. Perawatan ortodontik cekat umumnya memerlukan waktu perawatan 1- 2 tahun untuk kasus yang tidak parah. Apabila perawatannya lebih dari 2 tahun mungkin saja karena penggunanya yang kurang disiplin atau kurang kooperatif selama menjalani perawatan. Pengguna alat ortodontik yang kurang disiplin menyebabkan pergerakan yang diharapkan dari penggunaan alat ortodontik cekat yang digunakan menjadi tidak tercapai atau lambat dicapai. Kondisi ini berdampak pada lamanya waktu yang dibutuhkan untuk perawatan dengaan 
menggunakan alat ortodontik cekat. Perilaku yang kurang disiplin ini juga dapat merupakan gambaran dari perilaku pengguna alat ortodontik cekat dalam memelihara kebersihan gigi dan mulutnya. Apalagi dengan menggunakan alat ini permukaan gigi cenderung kurang bersih oleh karena adanya bracket yang menempel pada permukaan gigi. Bentuk anatomis bracket yang ada memudahkan sisa makanan untuk tersangkut. Pengguna alat ortodontik cekat yang kurang disiplin dalam menjaga kebersihan gigi dan mulutnya akan tergambar dari kondisi permukaan giginya yang kurang baik. ${ }^{9,10}$

\section{SIMPULAN}

Status kebersihan gigi dan mulut siswa pengguna alat ortodontik cekat pada umumnya tergolong baik.

1. Status kebersihan gigi dan mulut siswa berjenis kelamin laki-laki dan perempuan rata-rata tergolong baik.

2. Kebersihan gigi dan mulut siswa dengan tingkat sosial ekonomi orang tua tinggi rata-rata tergolong baik dan siswa dengan tingkat sosial ekonomi sedang rata-rata tergolong sedang.

3. Status kebersihan gigi dan mulut siswa yang menggunakan alat ortodontik cekat di bawah 1 tahun dan 1 - 2 tahun rata-rata tergolong baik dan lebih dari 2 tahun rata-rata tergolong sedang.

\section{SARAN}

Diharapkan UKGS dapat memanfaatkan data hasil penelitian untuk digunakan dalam penyusunan program kerja untuk mengoptimalkan upaya promotif dan preventif kesehatan gigi dan mulut masyarakat di Sekolah wilayah kerjanya. Bagi masyarakat pengguna alat ortodontik cekat yang belum memiliki perilaku yang benar dalam pemeliharaan kebersihan gigi dan mulutnya agar dapat memerhatikan kebersihan gigi dan mulutnya serta memeriksakan giginya secara teratur kedokter gigi. Kepada pihak sekolah tempat penelitian dilakukan agar dapat mendorong para siswa pengguna alat ortodontik cekat untuk dapat mempertahankan perilaku yang baik dalam pemeliharaan kebersihan gigi dan mulutnya terlebih khusus selama menjalani perawatan ortodontik.

\section{DAFTAR PUSTAKA}

1. Riskesdas. Riset kesehatan dasar, Laporan Nasional Riskesdas 2013. Badan Penelitian dan Pengembangan Kesehatan Repoblik Indonesia. Available from URL: http://www.litbang.depkes.go.id/Lap oran RKD/Indonesia/Riskesdas2013

2. Mantiri SC. Status kebersihan mulut dan status karies pada mahasiswa pengguna alat ortodontik cekat. Journal e-GiGi. 2013. Vol 1 No 1

3. Proffit RW. Comtemporary Orthodontics. $3^{\text {th }}$ ed. St. Louis: CV Mosby CO, 2000. p. 228-40.

4. Ramdhani GS. Fenomena fixed orthodontic (behel) antara pemborosan dan kebutuhan. Kompasiana. [cited 14 juni 2014] available from: URL:http//www.kompsiana.com/fen omenafixedorthodonticbehelantarap emborosandankebutuhan_files/

5. Moslehsadeh K. Simplified oral hygiene index. July 2011 [cited 2014 Jul 7]; URL:http://www.mah.se/CAPP/Met hods-and-Indices/Oral-HygieneIndices/Simplified-Oral-HygieneIndex--OHI-S/

6. Manueke MP. Hubungan lama penggunaan alat ortodontik cekat dengan status gingiva pada mahasiswa program studi pendidikan dokter gigi universitas sam ratulangi [Skripsi]. Manado: Fakultas Kedokteran, 2014. p.31.

7. Pimtip. A clinical survey of removable partial denture after 2 years usage [Thesis]. Australia: University of Sidney.

8. Sogi G, Bhaskar JB. Dental caries and oral hygiene status of 13-14 year old scholl children of davangere. Journal Indian Sot Pedo Prev Dent 
[serial online] 2001 [cited 2014 agustus 24]. Available from: URL:http/medind.nic.in/jao/t02i4p1 52o.pdf

9. Wowor VE. Hubungan antara status kebersihan mulut dengan status karies siswa sekolah menengah atas negeri 1 Manado [Skripsi]. Manado. 2013. p. 4

10. Zachrisson S, Zachrisson BU. Gingival condition associated with orthodontic treatment. Angle orthod. 1972;42(1): 26-34. 